\title{
DESIGNING FROM CINEMA: FILM AS TRIGGER OF THE CREATIVE PROCESS IN ARCHITECTURE
}

\author{
Iñaki Bergera \\ Universidad de Zaragoza (Spain) \\ ibergera@unizar.es
}

Received January 2018

Accepted February 2018

\section{Abstract}

The present paper examines, in a case study format, the use of films, short films and audiovisual documentaries as reasoning and references for design assignments during the first years of an architectural degree course. The aim of this fruitful and comparable experience is not so much to study and verify the well-known synergies between film and architecture, but to emphasize the methodological importance of endowing students in their first experience of design projects with realistic and feasible support - through visual references - that can increase their awareness of the desire for realism to which every project aspires. Project simulacrum finds an ally in the realistic fiction present in film. The association between film and architecture is thus placed at the service of learning and design methodology, as a means, not as an end.

Keywords - Project, Methodology, Narrative, Film, Visuality, User.

\section{Introduction}

My long teaching experience as the head of architectural design courses for architecture degree students in their first years has, unintentionally, allowed me to give continuity to an approach and format for exercises whose virtues and effectiveness can now be enhanced and examined in perspective. To date, and over the last decade, a total of eight films and short films and documentaries have served to structure the tasks and aims of assignments we set for students.

The fact that topics such as place, design briefs and, significantly, the final user of the project encounter a form of real materialization in the story told by a film allows us to verify, by means of the tangible results of such exercises, that establishing this connection with the real narrative parameters present in an audiovisual assists students taking their first steps in the practice of architectural design to establish bridges that allow them to achieve the desired credibility to which all design projects aspire.

The preliminary stages of project design learning are for students like an empty and unexplored lava field, where the absence of tools and references, and the abstract nature of the design methodology we defend - which prioritizes the idea as the justification of form - can cause a disconnect with the requirements of reasoning and credibility in architecture. This educational experience confirms that telling a story - having a visibly credible context and characters - stimulates students to achieve greater and more correct and solid engagement with the question posed by every project. 


\section{Film as an Excuse and Means for Design}

Transferring the interpretive and theoretical discourse of the relationship between architecture and cinema to the field of education may be seen as ambitious and redundant at the same time. As reflected by the large number of bibliographical references in this respect, architecture and film share countless similarities that allow both disciplines to mutually influence the discourse of the other. Both share a real and metaphorical space, a setting, but above all they maintain narratives involving space and time that cannot be imagined outside of the phenomenology of those who live and act in their screenplays and existential stories. Architecture constructs spaces, while film constructs a way of viewing those spaces in time.

Surely this exploration of relationships is where the tyranny of the visual is most tangibly seen as a source of knowledge, spatial experimentation and, in a nutshell, learning. Also from an educational perspective, this reality obligates us to take a first critical standpoint: we do not show students films in order to enable them to design without making intellectual efforts, or so that they grasp the message, literally, through their eyes. It is not our intention to give students an illustrated manual - a book with photographs - so that they learn only by seeing. In this case, would it not be equally productive to have a design exercise in the form of a text heading without images to stimulate the imagination and creativity even more? Would it not be equally exciting, for instance, to base a project on Species of Spaces and Other Pieces by Georges Perec? We prioritize the visual, but with the sole purpose of critically educating the eye, and of exploring its potential for analysis and deduction as an unavoidable tool in the service of the design. Learning to "read" an image, whether fixed or in motion, involves learning to utilize the language and visual and narrative syntax of our complex contemporaneity. As Martínez-Santa-María explains, "The theoretical foundation on which our type of project is based is that of teaching to see. Once again, the ancient language insists on the deeper and at times lost meaning of each word: the Greek theoria means viewing, sight" (Martínez-Santa-María, 2004: page 105).

This practice in the teaching of design does not seek to train students in the cinematic arts or to explore formal relationships - architecture as a natural film set - with the art of construction. We start with the premise of a double-sided game of simulation: film as the telling of a story-fiction, and the design project assignment as the chimera of an architecture without aspirations of being built. Film and project share a screenplay and a story, and exist for the illusion of what they want to become: a figurative pseudo-reality that crystallizes their respective imaginary spaces within the two dimensions of the screen and the paper, respectively. Film shows us and makes use of the set for action and life. The spatiality and direct connotations with the use its "actors" make of it are revealed without intermediaries other than those of the actual cinematographic language. As we will see, an attempt has therefore been made to choose films in which space is the protagonist, either as an assertion or as a criticism. For reasons of scale and the ability to control, the domestic space is where interrelationships become more intense. "The domestic space, the real home or one built for the occasion, plays a specific role in the effectiveness of the account, to the extent that one would not exist without the other" (Ortiz-Villeta, 2008: page 55).

Set and actor, space and user; when designing, students must understand that they are pursuing a spatial and formal idealization that makes the life of those real actors, the people who are users of the architecture, possible. These designs inspired by film obligate students to choreograph the difficult balance between fiction and reality where, most likely and for reasons of effective teaching, the most credibility is gained by borrowing a client - the character - from that fictitious reality. The main characters of these films - many of which are dramas - tend to be extreme individuals with very strong personalities. This profile serves to allow students to design in accordance with those well-delineated features, and to understand that any project must be adapted to the type of client. The designed space will not be just any space; it is a space designed to fit somebody they know.

Students act as spectators in relation to the film. By borrowing characters from the film for their project, they are asked to be spectators involved in the space they are designing. As Miguel Marías pointed out, "A film is going to be our house, the spatial and temporal edifice which we are going to inhabit for ten, forty, eighty or one hundred and twenty minutes" (Marías, 2008: page 6). This celluloid "home" must therefore 
be liveable, understandable and comfortable; we might think that the setting of a film or its leading characters can also break free of their visual fiction to feed the ideas and aspirations for credibility of a project assignment. While many directors have paid special attention to the spatial and temporal construction of their films, showing care for the formalization, arrangement and experience of sets, it is our belief that architectural projects can also extract information, characters and details from film that will contribute by their apparent realism to the structure - endowed with conceptual meaning - of an architectural design project. While the film brings the set to life, we would like students to pursue the idea that the design project brings architecture to life.

Cinema and architecture are, as Juan Antonio Ramírez wrote, "two such different arts that it could well be said that they are radically incompatible: the solidity and physical nature of architecture would be opposed to the flickering and evanescent conjuring of what is being projected onto the screen" (Ramírez, 2008: page 12). As far as we are concerned, however, this apparent incompatibility has an inverted logic: what we see in a film, those characters and places, are much more "real" than the architecture students have to design in their projects. Coming to know "real" characters through images, their context, their personality and more particularly, through their relationship with the space they inhabit is much more plausible and credible that an architecture that aspires, at most, to the best of its graphic representations. By using a film for the design project-related exercise, we help students to understand the nature and real purpose of designing. What is borrowed from cinema - essentially fiction - is its documentary and (neo)realistic nature. Our intention is that the project, the act of designing, should lose its blurred and ethereal character in order to become impregnated with humanity and credibility.

\section{Specific Experiences}

As explained previously, this design exercise emerged unintentionally, and therefore the choice of films used, while not random, did not respond to criteria - especially cinematographic ones - other than their suitability and adaptability to the topic of the end-of-year assignment, and they were almost always completed within a time scale of seven weeks. Some of the film titles were well-known, and others less so. The following is a chronological presentation of works, exemplified by a number of representative students' designs.

\subsection{The Dream of Light. Projects 1, Academic Year 2009-10}

The intense poetic and creative nature of the documentary by Víctor Erice, which describes and accompanies the slow and intense process by which Antonio López paints, served the intention of exposing students to and having them face the same reality in relation to the design project in architecture. This is understood not as a formal or functional problem for creating a particular object, but more as a radical approach to the essentials: living, inhabiting, working, thinking and creating. The project aimed to unsettle students and to make them forget what went before: beginning a design from scratch, bringing them face to face with bare creation.

With the students inspired by the visual brilliance of the film as it showed the delicate and fascinating dialogue between the painter's contemplation of the quince, as captured and told by the camera, they were introduced to an exercise on the discourse of space. Following the screenplay, understood as a dance of sensations to the rhythm of light and the passing of time, and arranged by the way the characters were interpreted, the exercise consisted of the materialization of the abstract space as a set in which this visual choreography could be re-enacted. The aim was not to design a home and studio for López, but a space or spaces for the quince, which was understood to be the object around which the eyes and actions of the characters revolved. The key to the exercise was the visual analysis, and therefore the process: only by understanding what was happening and how and why it did so could a new space be later structured according to a design brief proposed by the students, as a series of spaces given form through volumes, scale and light. The new design had to allow the things taking place in the film to happen and that the characters appearing in the film to "act". 


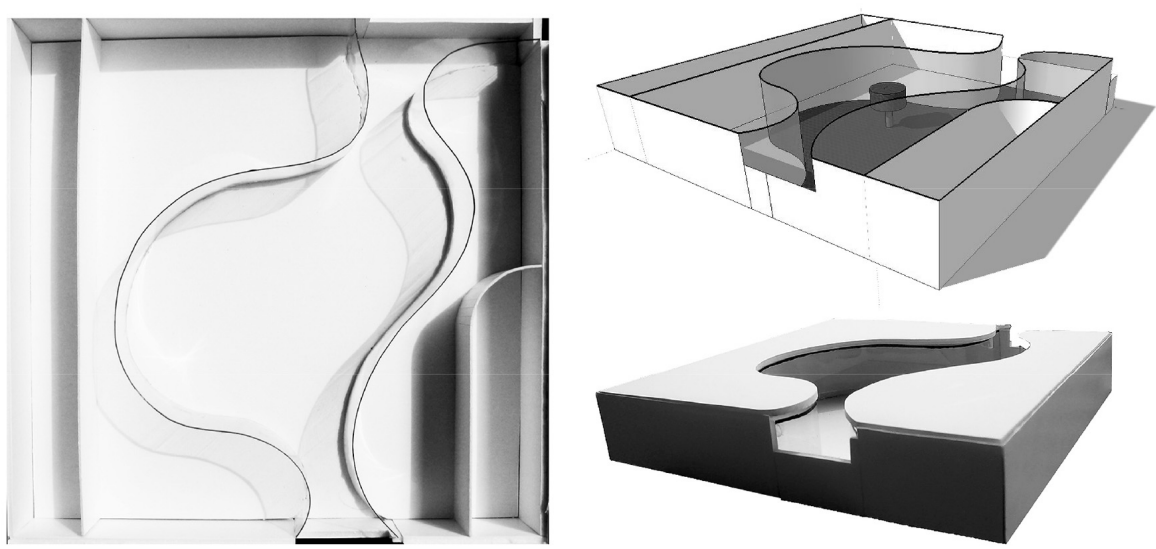

Figure 1. The space for the quince. Student: Sergio Tejero (2009)

\subsection{Mon Oncle. Projects 2, Academic Year 2009-10}

Viewing this film is almost compulsory in this context. The exercise was based on one of the best critiques ever made on the contradictions, inflexibility and excesses of modern orthodoxy, as analysed by Iñaki Ábalos (2008), among others. The film considers the radical dichotomy between the modern and rational way of life and a carefree, romantic and anarchic lifestyle. The Arpel family, consisting of Monsieur and Madame Arpel and their son, live in a "modern" house with a garden on the outskirts of the city. Monsieur Hulot, the boy's uncle and Madame Arpel's brother, lives in a ramshackle flat in a rundown building in the centre of Paris. Despite the attempts of his family, the boy rejects his imposed and routine adaptation to the modern life of his house and is drawn to his uncle's amusing life and the genuine attitude he has towards his activities.

Independently of the film's plot - at times verging on the over-exaggerated and the absurd - the exercise was meant to squarely resolve this conflict through a hypothetical architectural solution. We imagined the boy as a mediator, imploring the parties to find a solution by consensus. Given the extremes represented by the two alternatives, the solution would be the construction of a new residence to house all these individuals, providing them with a common ground for co-existence in which they would all feel comfortable and identified. The ambitious solution was to resolve the problem of architectural language, on the one hand, and the way of life associated with it, on the other. There could not be two homes in one, only a single, compact or fragmented one, with a cohesive image that would be located, in this case, on one of the chamfered corners of the early twentieth-century expansion area of the city of Zaragoza.
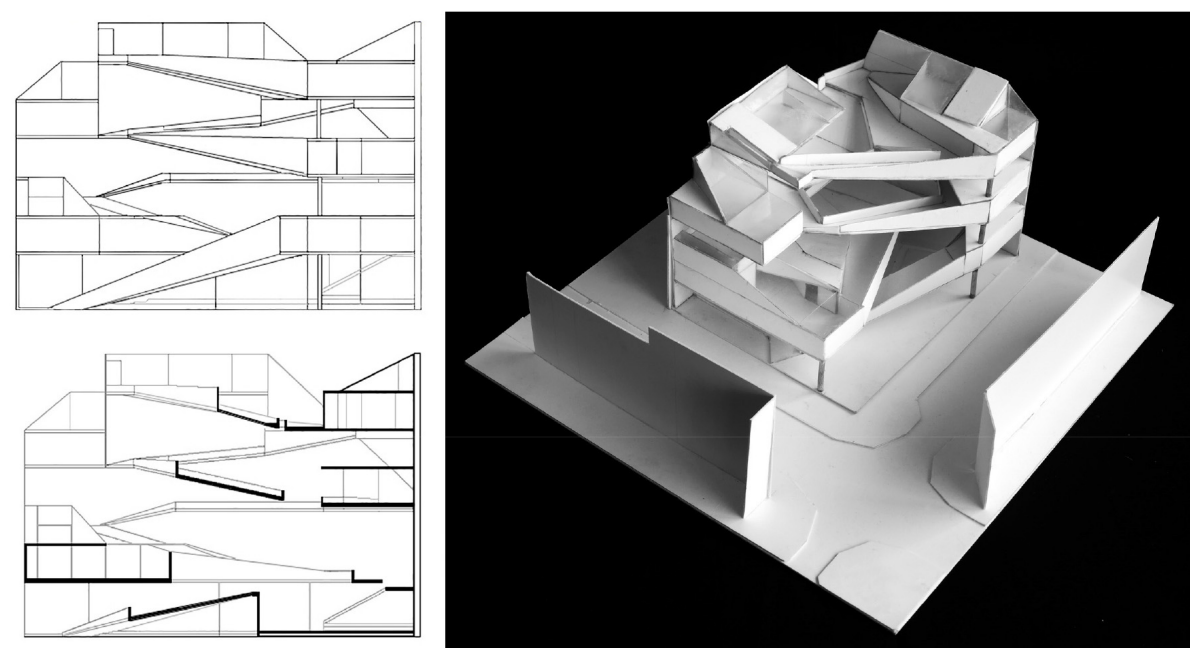

Figure 2. Not without my uncle. Student: Esther Caballú (2010) 


\subsection{Garage. Projects 2, Academic Year 2010-11}

This Irish feature film is an account of everyday life as experienced by Josie, who has spent his whole life as the attendant of a decrepit service station in the Irish countryside. Josie is shy and solitary, quite optimistic and, in his own way, content. Regardless of its plot and ending, the film deals sensitively with the concept of contemporary loneliness in the midst of social and personal relationships, and the friendship, trust and kindness through good and bad times as experienced by Josie in his dealings with the new service station employee and his friends, with the village shopkeeper, with the service station owner, with the locals at the pub and with his customers. Based on an understanding of the character, the purpose of the exercise was to give Josie a more pleasant and decent life by building a new service station and adjoining residence on the pre-existing plot.
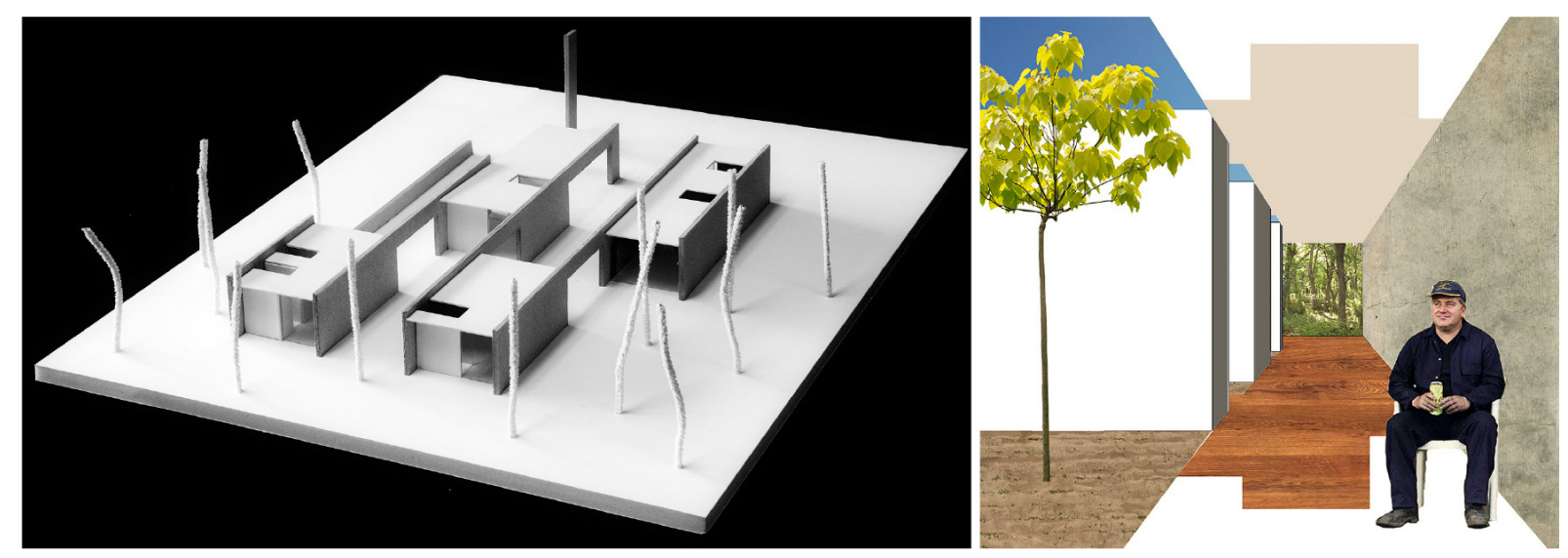

Figure 3. A space for Josie. Student: Jorge Ruberte (2010)

Students therefore had to analyse the character in depth in order to adapt the resulting design to his needs. Loneliness, happiness, the public and private spheres, the domestic side and work side are ambitious themes and complex relationships that would have to be connected in order to provide a suitable architectural response to all of them. The hybrid nature of the required use - a residence as part of a service station or a service station with residence - led to the questioning of the identity of each of these programmed units and to formally and intelligently respond to their co-existence.

\subsection{Dogville. Projects 2, Academic Year 2012-13}

The story of Dogville is set in a small town in the middle of the United States during the Great Depression. The town is represented in an abstract, two-dimensional way, and the action takes place as if on a theatre stage. In addition to the symbolism, morality and interpretation that can be made of the harsh plot - in close alignment with the profile and career of its director, Lars von Trier - the film provides a topographic, urban, collective, and individualized, residential and architectural context that served for the design exercise. Although it was not the topic of the project, this film was of particular use to students as it enabled them to deepen their understanding of the language and discourse of cinema as a major part of contemporary visual culture.

The project involved a first level of collective thought associated with the urban structure and the location of the town. A real location was given in the form of a large expanse of land close to the Aragonese town of Alcañiz, for which the students as a group had to choose the location and programme of uses that would comprise an entire town. The first part of the assignment, therefore, consisted of an analysis of those uses, and the types of buildings and users, in order to define the urban and landscape interventions required prior to the creation of individual design projects. Once the topography and plans for the creation of the town in this new, real location were defined, each student was tasked with designing a specific project with the respective design briefs extracted from the content of the film, but updated to the contemporary context. The number of residents per home, their age and idiosyncrasies were 
maintained. Without taking the screenplay further into account, the project did address the desire that good architecture should reflect individual and collective lifestyles.

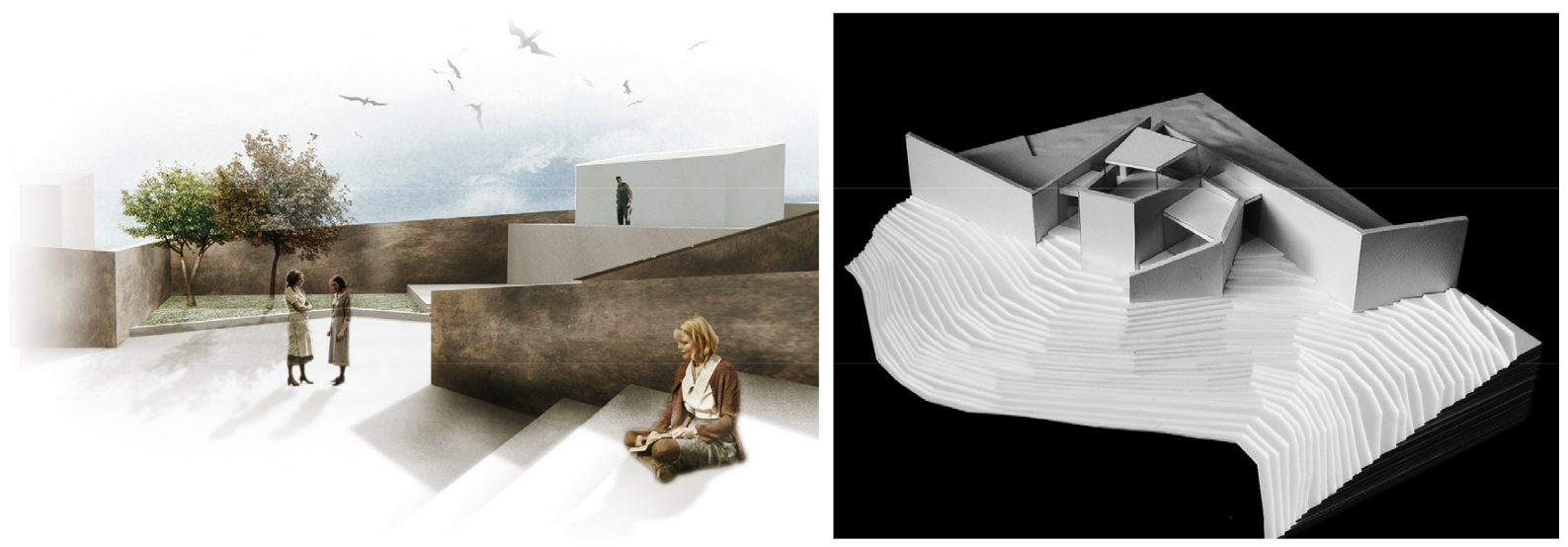

Figure 4. Dogville, inhabiting the wall. Student: Alejandro López (2013)

\subsection{The Search of Emak Bakia. Projects 2, Academic Year 2013-14}

This exercise was intensely focused on the suggestive nature of design, on its idea and its justification from its initial conception, based on profound and definitory knowledge of the character-client. Based on that, and with more value placed on the process - intuition, chance, searching - than on the actual results, the exercise had to be also, and essentially, about architecture: a specific response to the conditioning factors of the programme, place, context and culture. The exercise was the continuation of the story presented by the film The Search for Emak Bakia, which revolved around the search for a house, Emak Bakia, which had given its name to an earlier film by the surrealist artist Man Ray. In a way, the project was that film, to the extent that the architectural design that the students had to create was that of a new Emak Bakia for Oskar Alegría, the film's director. The students had to know their client through the film, and sense and interpret what the director would have wanted. By continuing the director's search, his processes, passions, decisions, sentiments, admiration and sensibilities could be understood and turned into a residential programme, room, house and home; i.e. architecture.
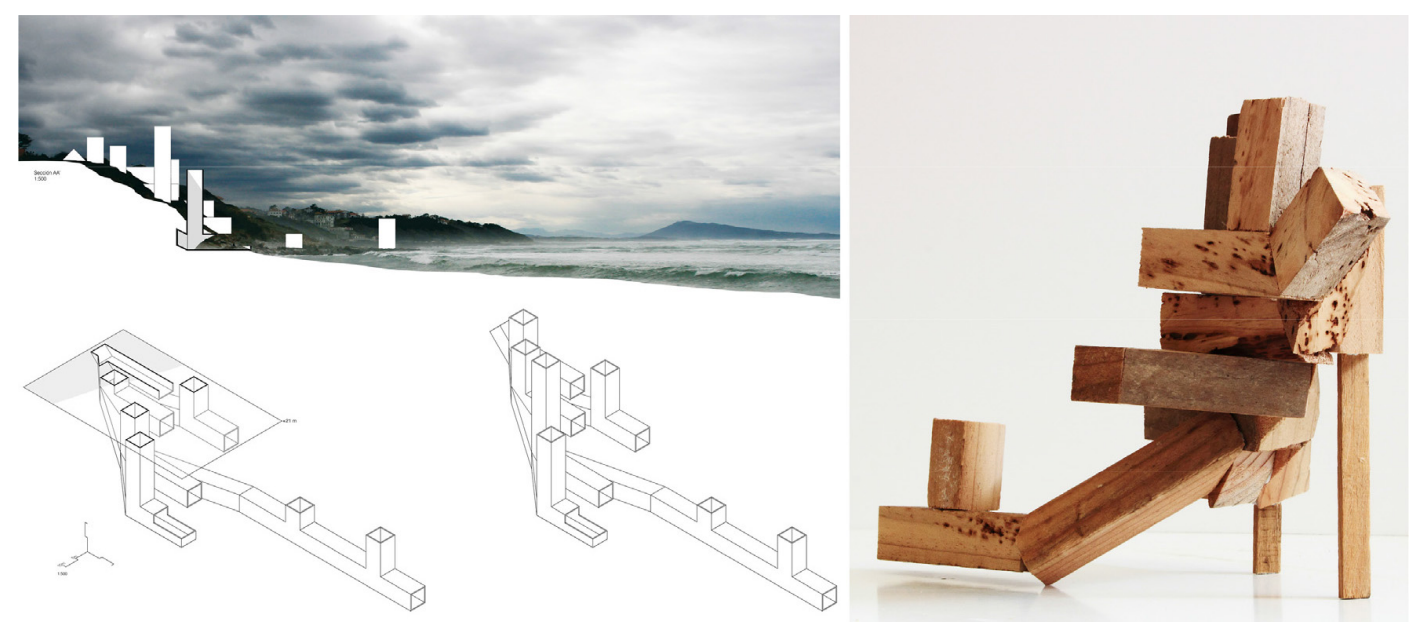

Figure 5. Emak Bakia! Student: Víctor Lucía (2014)

The exercise therefore consisted of designing a new Emak Bakia for Oskar Alegría on the same plot of land as the original. The residential programme for the house was precisely the stimulus for the project, given that its definition was the first decision students had to make after viewing the film, and the speculative insertion of what would be Alegría's needs and wishes for his dream home. By specifying the design brief, the project would draw from the tools of the architectural discipline in order to satisfy the director's profound sensitivity and delicate creativity. 


\subsection{The Man Next Door. Projects 1, Academic Year 2014-15}

The exercise consisted in requesting students to design a house adjacent to one of iconic design, so that their first encounters with the blank page and the first lines drawn from their creativity should have this reference as a preliminary support. This support was in turn reinforced by the visual narrative of an intense interpersonal relationship. The film deals with a seemingly endless conflict between neighbours. A simple party wall can separate two different worlds: two different ways of dressing, of eating, of living, among others. On one side lives Leonardo, a refined and prestigious designer whose house is an icon of modern architecture. On the other lives Víctor, a rough, unmannerly and overbearing used-car salesman. Víctor decides to put in a window to bring in more light, which gives rise to the problem: each neighbour becomes aware of the other's existence.

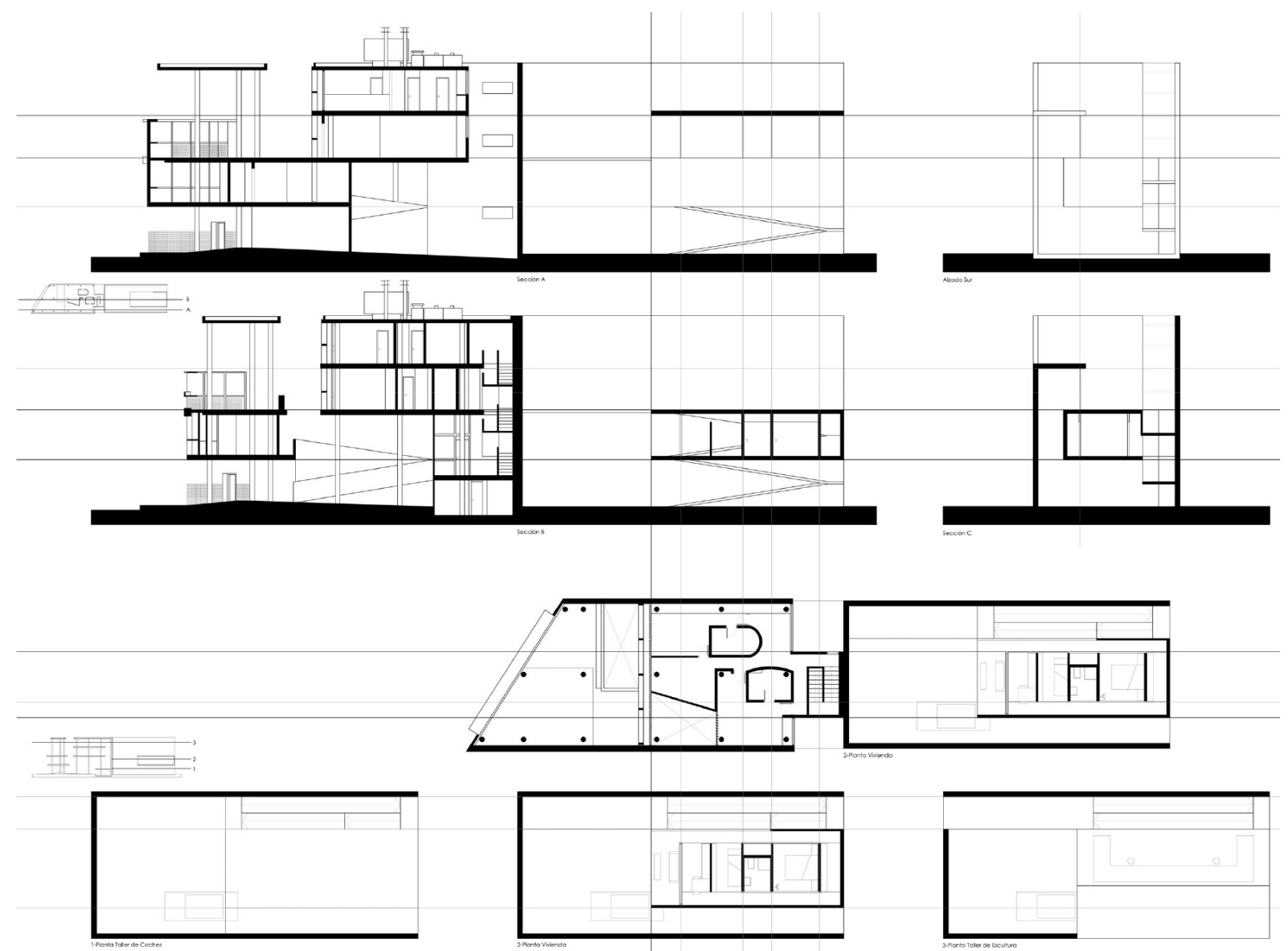

Figure 6. Catching a ray of sunlight. Student: María Sánchez (2014)

Independently of the other issues that give the film its interest and appeal, the fact that it is set in the Curuchet House - originally designed by Le Corbusier and built under the supervision of Amancio Williams between 1949 and 1953 in La Plata, province of Buenos Aires, Argentina - makes this film the justification for the project. In fact, the assignment set for the students was to build a house adjacent and contiguous to Curuchet House, in order to satisfy the design brief set out by Víctor and his uncle Carlos. The premise for the design, in addition to satisfying the functional programme, was to give Víctor's new house "a ray of sunlight" from the plot occupied by Curuchet House, the requirement that triggered the plot of the film.

\subsection{The Cyclops of the Sea. Projects 1, Academic Year 2015-16}

This project wanted to stress the conceptual and radical nature of the very idea of inhabiting space. Through the relegation of other typological aspects of architectural form, its aim was to investigate other notions that are inseparable from the very origins of architecture: the cave as the origin of the inhabited 
space. A bunker would be the first room: a generic space domesticated by functions and for the objects that occupy it. As the aim of the exercise was so restrictive, students had to cancel out any prior information in order to analyse, look, investigate and propose with freshness, radical thinking and discipline. For this, we were guided by a beautiful animated short film whose soundtrack consisted exclusively of music by Jann Tiersen (Amélie). The film tells the story of a cyclops who is the keeper of a lighthouse in the middle of the sea, which is also his home. The drama of his loneliness also results, after a raging storm, in the drama that affects his living space and the objects - animate and inanimate, possessed or desired - that give meaning to his life.
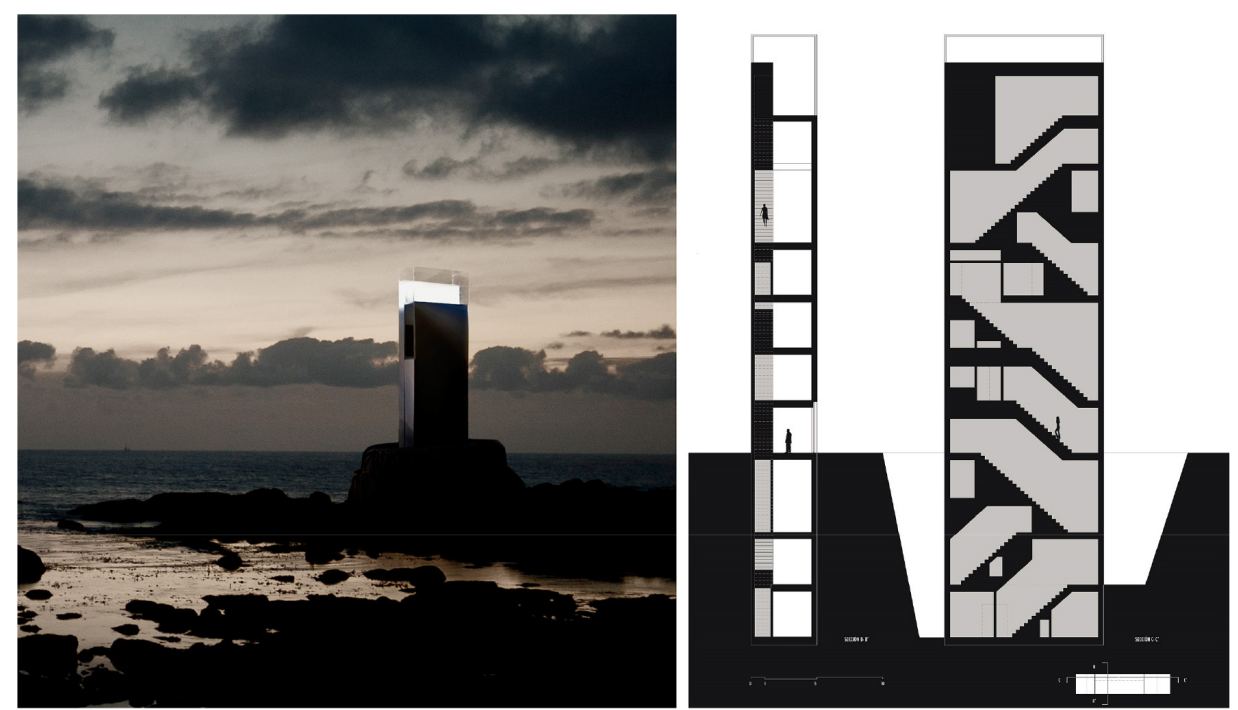

Figure 7. The cyclops of the sea. Student: Isis Pérez (2016)

The exercise proposed, hypothetically, going out to help the cyclops after his misfortune in order to rebuild his place of work and residence, at his request. After the frustration caused by the storm, the cyclops wants to build a new lighthouse and a refuge at its base that will protect him from future storms; he will have to be able to live and to move his things there: his bedroom, his workshop where he carves and makes gadgets, and his odds and ends, and a place to store his objects, among others. Also, taking into account his yearning for friendship and company, there will have to be a space in his refuge for a potential guest. By setting aside the mythological nature of the character, and likening him to a human, the aims of this exercise were to understand that a project such as this, which is highly charged both emotionally and creatively, would have to be resolved through radical thinking, going to the essence of things, and designing an intervention that lacked any ambiguity while being filled with intentions.

\subsection{Room. Projects 2, Academic Year 2016-17}

This exercise was based on a dramatic but thrilling film for the purpose of exploring elementary conditions and the concepts most genuinely associated with living in a place. The film is a harsh depiction of the experience of a young kidnap victim and her son who was born while held hostage and who, in consequence, has never had experiences outside of his minimal shelter, a single space in the form of the room which gives its name to the film. This traumatic situation is overcome by the woman who orchestrates the child's escape by tricking their abductor. The story leads to a situation that allows us to explore how a person learns about the world and his room after having practically no experience of it until the age of five. 

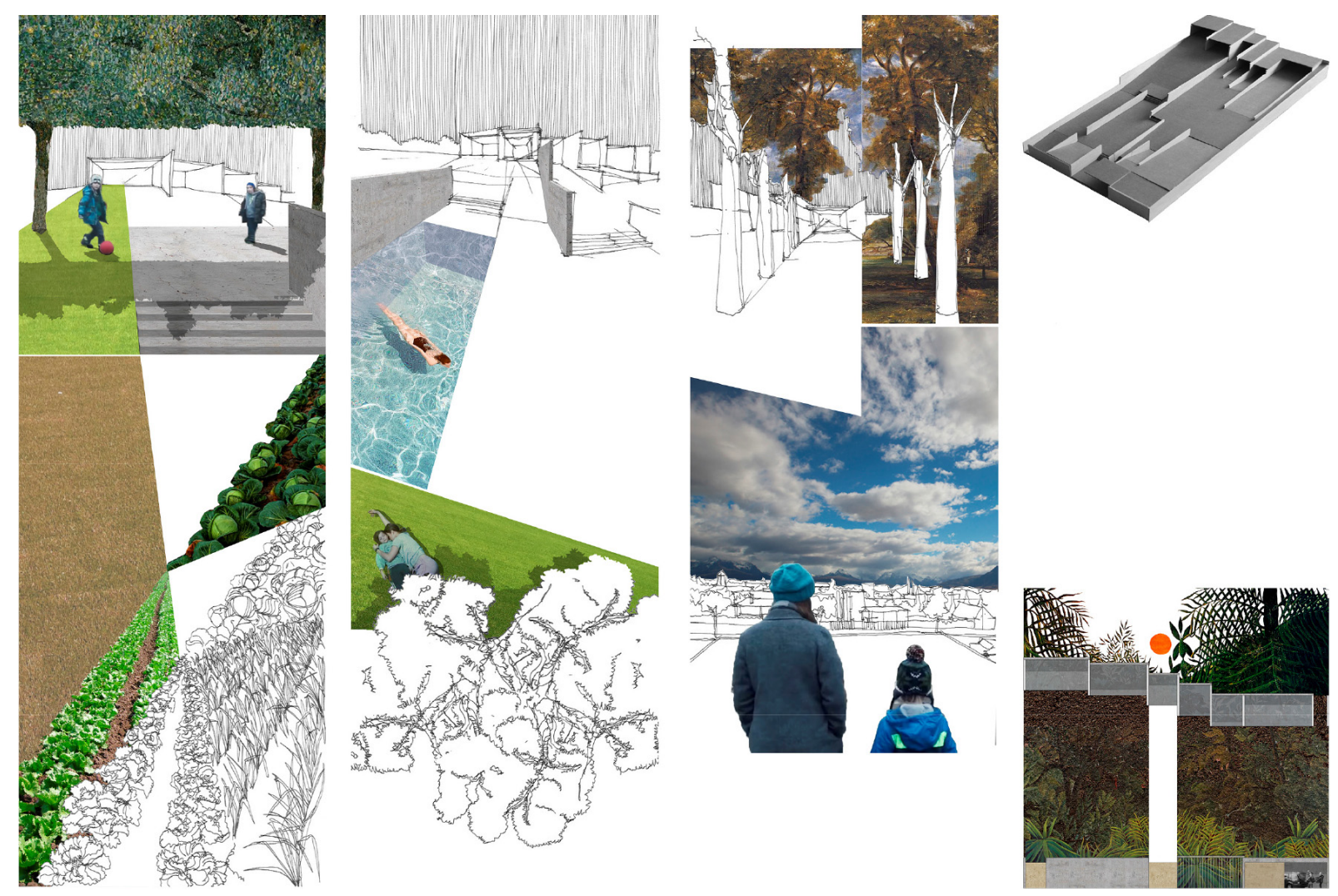

Figure 8. The room. Student: Carlos Puente (2017)

The assignment involved designing a home for these two people, with particular attention to the child's need to learn. A result was the possibility of considering a sequence of experiences related to the concepts and realities which are taken for granted by most people, while for the young character of the film they become a sequence of discoveries. These discoveries had to be translated into architecture: the relationship between interior and exterior, the visual appropriation of the sky and the horizon, control of light, and the spatial connotations of the public and private spheres. Both the students and the character in the film had to start from scratch to understand and create architecture.

\section{Conclusion}

Presenting this contrasted case study - the positive result of some of the exercises had already encouraged us to disseminate and publish the experiences (Bergera, Delgado Orusco, Leache Miguel Guitart \& Morón, 2015) - allows us to establish a certain paradigm and a clear connection between experimental and disciplinary approaches to teaching in architecture. Critically, its purpose is to corroborate in a contemporary and generational context the unavoidable predominance of audiovisual culture in relation to other sources of knowledge, and, going beyond the accepted transfer and the interdependence between cinema and architecture, to understand how visual narratives instils in young learners of project design an effective awareness and greater engagement in the actual process and in the acquirement of results.

There is no room here to explore and critically review those results, which serve us here to illustrate the present text. However, we can assert that the starting point - the film - does not restrictively condition learning; rather, given the variety and quality of the projects created by the students on the same topic, it serves as a stimulus for both ideas and for the spatial formalization derived from them. Celluloid stories and characters cease to simulate and are turned into reality in the eyes and minds of students, allowing them to work with conviction and learn with a basis of certainty. Architecture, the design project, continues to be a chimerical exercise for them, but less of one. 


\title{
Declaration of Conflicting Interests
}

The author declared no potential conflicts of interest with respect to the research, authorship, and/or publication of this article.

\section{Funding}

The author received no financial support for the research, authorship, and/or publication of this article.

\section{References}

Ábalos, I. (2008). La máquina de habitar de Jacques Tati: la casa positivista. In Ábalos, I. (Ed.), La buena vida. Barcelona: Gustavo Gili.

Bergera, I., Delgado Orusco, E., Leache Miguel Guitart, J., \& Morón, A. (2015). Emak Bakia! Procesos de diseño en torno a la casa Emak Bakia de Man Ray. Valencia: General de Ediciones de Arquitectura.

Dogville (2003). Dir. Lars von Trier. Zentrope Entertainment.

El hombre de al lado/The Man Next Door (2009). Dir. Mariano Cohn, Gastón Duprat. Aleph Media.

El sol del membrillo/The Dream of Light (1992). Dir. Víctor Erice. Igeldo P.C., María Moreno P.C.

Emak Bakia baita/La casa Emak Bakia/The Search of Emak Bakia (2012). Dir. Oskar Alegría. Emak Bakia Films.

Garage (2007). Dir. Lenny Abrahamson. Element Pictures.

Le cyclope de la mer/The Cyclops of the Sea (1998). Dir. Philippe Jullien. JPL Films, Arte.

Marias, M. (2008). Ver más y mejor (prefacio). In García-Roig, M. y Martí-Arís, C. (Eds.), La arquitectura del cine. Estudios sobre Dreyer, Hitchcock, Ford y Ozu. Barcelona: Colección Arquia/Temas 24, Fundación Caja de Arquitectos.

Martínez-Santa-María, L. (2004). Intersecciones. Madrid: Rueda.

Mon Oncle (1958). Dir. Jaques Tati. Gaumont Distribution, Specta Films, Gray-Film, Alter Films.

Ortiz-Villeta, Á. (2008). Donde habita la memoria. In Ortiz-Villeta, Á. (Ed.), La arquitectura en el cine. Construyendo una ilusión. Valencia: MuVIM.

Ramírez, J.A. (2008). Arquitectura e imagen móvil: el espectáculo debe continuar. In Ramírez, J.A. (Ed.), Los espacios de la ficción. La arquitectura en el cine. Valencia: Iseebooks.

Room (2015). Dir. Lenny Abrahamson). Film4, Irish Film Board, Telefilm Canada, Filmnation Entertainment, Element Pictures, No Trace Camping.

\author{
Published by OmniaScience (www.omniascience.com) \\ Journal of Technology and Science Education, 2018 (www.jotse.org)
}

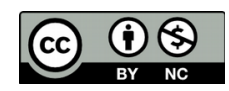

Article's contents are provided on an Attribution-Non Commercial 4.0 Creative commons International License. Readers are allowed to copy, distribute and communicate article's contents, provided the author's and JOTSE journal's names are included. It must not be used for commercial purposes. To see the complete licence contents, please visit https://creativecommons.org/licenses/by-nc/4.0/. 